\section{STATUS OF PROFESSIONAL CIVIL SERVANTS}

$\mathrm{T}$ HE recommendations of the Emergency Executive Committee of the Institution of Professional Civil Servants, which it is claimed represents more than 30,000 members of all grades and classes of the professional, scientific and technical staffs of the Civil Service, for the post-war reconstruction of the technical Civil Service, are summarized in a pamphlet recently issued by the Institution (Pp. 4). Broadly, the proposals aim at common salary scales for all professional classes, and a high standard of recruitment and service conditions which will attract to the service of the State the best brains in Great Britain. Within the membership of the Institution there are more than five hundred grades, and the Institution takes the view that the calibre of the officer should be the touchstone in deciding remuneration and that there is no reason why fully qualified scientific workers, engineers, architects, surveyors, etc., should not be paid on common scales. The education of the fully qualified professional man has been such that it produces a man at least equivalent in calibre to the normal entrant to the administrative class, and accordingly the remuneration of the fully qualified technician or scientific man should be on a parity with that of the administrative class. It is proposed that there should be three classes in the Service, each class being normally divided into two grades. Above this basic structure there should be directing posts, the salaries of which would be fixed according to the responsibility of the post. The three classes are designated principal class, executive class, and ancillary class.

Recruitment to the principal class should be from those possessing full professional, scientific or technical qualifications, such as a first or second class honours degree in the relevant science, or membership of the appropriate technical institution. The two grades within this class would be assistant principal and principal, appropriately amplified by fuller titles for different branches of work (for example, assistant principal engineer, principal scientific officer); and the grades should carry parity in remuneration with the assistant principals and principals of the administrative class (at present $£ 275-£ 625$ and $£ 800-£ 1,100$ a year). The members of the executive class would generally work under the direction of members of the principal class and undertake normal technical duties, as well as supervisory duties in workshops and laboratories where full professional qualifications are not required. Recruitment would normally be at the age of eighteen to nineteen years from persons with a good standard of secondary education. The two grades within the class should have parity of remuneration with nontechnical executive officers (at present $£ 150-£ 525$ ) and staff officers and senior staff officers (at present $£ 550-£ 750$ ). In both these classes the maximum of principal or executive officer should normally be reached well before retiring age.

The third, the ancillary class,. would be responsible for routine duties for which it would not be appropriate to employ members of the executive class. It would be roughly comparable with the present clerical class, the standard of education of which is the general schools examination or matriculation. The greatest care should be exercised in the employment of young persons in the ancillary class. Those who show special ability should be afforded an opportunity of acquiring training which would qualify them for entry into the executive class, and this training should not involve undue evening work.

With regard to recruitment, central recruitment should replace recruitment on a purely departmental basis, with a central recruiting board for technical posts under the rgis of the Civil Service Commissioners, and composed of persons with wide experience of professional, scientific and technical staffing requirements. This board's duty would be to certify as eligible for posts in the Civil Service candidates whose qualifications fulfilled agreed standards. It should have the fullest co-operation of the universities and professional institutions, but actual appointments would be made by departmental or regional boards from among those selected by the central board. Since all staff would be recruited by the Civil Service Commissioners, they should be treated on the same basis as the non-technical Civil servants, and come under whatever superannuation scheme is agreed for the Civil Service as from their date of entry into the Service, instead of having to wait several years to qualify for pension rights as have the majority of technical staffs at present.

The reasons for these proposals, which the Institution believes would greatly strengthen the technical service of the State and enable it to play its full part in the post-war reconstruction of Great Britain, are set forth in fuller detail in a second statement prepared on the instructions of the Emergency Executive Committee (Pp. 16. 6d.). Some of the recommenda. tions, it is emphasized, are the considered views of that Committee; others are first thoughts, but all are capable of revision in the light of discussion among the membership. A brief report of the Conference on Post-War Reconstruction, held on March 4 and 5, when the draft proposals were considered is included.

Discussing the scope of the recommendations, the statement, recognizing that the professional, scientific and technical branches of the Civil Service noed a drastic overhaul, urges that it is essential that this side of the Service should play its part in shaping the post-war Civil Service as a whole, and that the whole Service will be intimately associated with the people in a way which would have seemed impossible before rationing, controls and the inescapable need for central direction of the national economy shattered the aloofness of the servants of the State. As the extent of the contribution of Civil servants to social welfare increases, they must ensure that their tasks are carried out with initiative, flexibility and a full understanding of their implications and repercussions.

In a brief survey of the functions of the professional, scientific and technical staffs, the statement quotes recent evidence that the importance of those functions is becoming more widely recognized, and refers to the approach of the Anderson Committee and the Tomlins Commission to the problem of simplification of the structure of this branch of the Civil Service. It notes that provision must be made for recruitment at higher age-levels to the principal class to obtain the benefit of experience outside the Service, and emphasizes that the duty of the central recruiting board should be limited to certifying the eligibility of candidates for appointment to the Civil Service, selections being made by the departmental or regional boards on the basis of interviews.

A section of the statement deals with the special problems of the immediate future, such as priority 
for permanent posts, redundancy, and recruitment at the termination of hostilities. The statement also emphasizes the desirability of the Appointments Department of the Ministry of Labour remaining in being after this transition period and not only registering the qualifications of professional, scientific and technical personnel, but also keeping a register of posts occupied by them, including at least the scale of remuneration of the post. The Institution's support of equal pay for men and women and opposition to the marriage bar is re-affirmed. Consideration of the possibility of the Civil Service Commission adding to its functions in order to become a body for determining stalaries is suggested, and an endeavour is proposed to restore the true functions of the Whitley Councils, which include the utilization of the experience of the staff in planning the work of the departments.

\section{FORTHCOMING EVENTS}

(Meeting marked with an asterisk * is open to the public)

Monday, December 11

ROYAL ANTHROPOLOGICAL INSTITUTE (joint meeting with the ENGLISH FOLK DANCE AND SONG SOOIETY) (at Cecil Sharp House, 2 Regent's Park Road, Iondon, N.W.1), at 6.30 p.m.-Dr. Ethel John Lindgren: "Shamanism-Some Manifestations in Manchuria".

Tuesday, December 12 CHADwICK LECTURE (at the Royal Society of Tropical Medicine
and Hygiene, 26 Portland Place, London, W.1), at 2.30 p.m.-Dr. George H. Walker: "Food and its Adulteration during the Present

Chemical EngineERING Group (joint meeting with the INSTITUTION of Chemical ENGINenRs) (at the Geological Society, Burlington House, Piccadilly, London, W.1), at $2.30 \mathrm{p} . \mathrm{m}$.-Mr. Norman Clarke Jones: "Forestry, and the Utilisation of Waste Wood and its Products as Fuel".

ROYAL INSTITUTION (at 21 Albemarle Street, Piccadilly, London, W.1), at 5.15 p.m.-Sir Henry Dale, O.M., G.B.E., Pres.R.S. : "Modern Developments in Chemical Therapeutics", (ii) "Recent Advances in Chemotherapy".

Tuesday, December 12-Wednesday, December 13

Agricultural EDdCation Association (at the London School f Hygiene and Tropical Medicine, Keppel Street, London, W.C.1).Yearly Conterence.

Tuesday, December 12 "At 9.30 a.m. (County Education Section)-Mr. F. H. Garner: Fungus Diseases of Field Beans".

At 10 a.m. (Biology Section)-Discussion on "Modern Methods of Pasture Evaluation" (to be opened by Messrs. William Davies and J. Lambert).

At 10.15 a.m. (Analysis of Fodders Sub-Committee)-Discussion on the Report on "The Sampling of Baled Dried Grass for Chemical Analysis".

At 11 a.m. (Dairying Section)-Mr. E. L. Crossley: "Dried Milk Production in War-time".

At 11.15 a.m. (Agriculture Section)-Dr. T. Wallace : "Some Aspects of Mineral Deficiencies in Farm Crops"; Mr. V. C. Fishwick: "The Influence of Nutrition during Early Life on Breeding Capacity and Milk Production'.

At 11.15 a.m. (Chemistry Section)-Mr. F. Knowles: "Notes on the Poisoning of Plants by Zinc",

At 2.30 p.m. (First Paper Reading Session)-Dr. C. Crowther: "Agricultural Education and the Work of the A.F.A., 1894-1944"; Wednesday, December 13

At 10 a.m. (Second Paper Reading Session)-Prof. R. G. White : "The Live Stock Industry in Britain during the last Fifty Years".

\section{Wednesday, December 13}

INSTrTuTs of FUEL (at the Institution of Mechanical Engineers, Storev's Gate, St. James's Park, London, S.W.1), at $2.30 \mathrm{p} . \mathrm{m}$.Mr. N. S. Pill

InstrTute of Petroleum (at 26 Portland Place, London, W.1), at 4.30 p.m.-Prof. V. C. Illing: "Exploration".

INSTITUTION OF ELECTRICAL ENGINEERS (TRANSMISSION SECTION) (at Savoy Place, Victoria Embankment, Iondon, W.C.2), at 5.30 p.m. -Mr. W. Szwander: "Valuation and Capitalization of Transformer Losses".

BRITISH INSTITUTION OF RADIO ENGINEERS (at the Neville Hall, Westgate Road, Newcastle-upon-Tyne), at 6 p.m.-Dr. T. H. Turney : "Wave Guides".

\section{Thursday, December 14}

GenETICAL SocIETY (at the Geological Society, Burlington House, Piccadillv, London, W.1), at 2 p.m.-Mr. D. G. Catcheside : "Nature of Lethals in Drosophila melanogaster", 1 : "Experimental" ; Mr. D. E. Lea: "Nature of Lethals in Drosophila melanogaster", 2 : "Theoretical"; Dr. G. Pontecorvo: "Genetic Aspects of Heterokaryosis"; Prof. J. B. S. Haldane, F.R.S., and Mr. H. L. K. Whitehouse : "Meiosis in some A scomycetes"; Mr. A. Haddow : "The Artiflcial Induction of Imitating Tumour Development"; $\mathrm{Mr}$. P. T. Thomas: "Experiments "Mutation-rate of Retinoblastoma in Man".

ROYal Instritumion (at 21 Albemarle Street, Piccadilly, London, W.1), at 2.30 p.m.--Prof. James Gray, F.R.S.: "Locomotory Mechanisms in Vertebrate Animals", (iv) "Relationship of Iimb Form to Habit and Environment-Evolution of Types for Climbing and Running".

INSTITUTYE OF FCEL (YORKSHIRE SECTION) (at the Chemistry Lecture Theatre, The University, Leeds), at 3 p.m.-Mr. D. W. Milner and Mr. E. Brett Davies: "Coal Tar and its Products as Fuel, and in the Chemical Field".

INSTITUTE OF PETROLEUM (joint meeting with the ROAD AND BUILDING MATERIALS GROUP OF THE SOCIETY OF CHEMICAT INDUSTRY) (at 1 Grosvenor Place, London, S.W.1), at 4 p.m.-Mr. P. Alexander and Mr. J. F. T.

INSTITUTION OF ELECTRICAL ENGINEERS (INSTALLATIONS SECTION) (at Savoy Place, Victoria Embankment, London, W.C.2), at 5.30 p.m. -Mr. J. C. B. Nicol: "Organization of Industrial Electrical Maintenance".

Pharmacedtical Society (at 17 Bloomsbury Square, London, W.C.1), at 7 p.m.-Dr. G. W. Scott-Blair: "Rheology and the Pharmacist".

BrItish INSTITUTE OF RADIOLOGY (in the Reid-Knox Hall, 32 Welbeck Street, London, W.1), at 8 p.m.-Mr. A. Craig Mooney : "Dise Lesions in relation to Pain" ; Mr. Hugh Davies: "The Symp-

\section{Friday, December 15}

SocIETY of Chemical INDUSTRY (Plastics Group) (at the Chemical Society, Burlington House, Piccadilly, London, W.1), at 2.30 p.m.Dr. R. R. Smith: "Kinetics of Vinyl Polymerisations in the Liquid Phase".

Royat InstiTution (at 21 Albemarle Street, Piccadilly, London, W.1), at 5 p.m.-Dr. L. R. G. Treloar: "Rubbers and their Characteristics, Real and Ideal";

Institution of Mechanical Engineers (at Storey's Gate, St. "Sames's Park, London, S.W.1), at 5.30 p.m.-Mr. E. J. Heeley: "Some Considerations in the Design of Class 1 Pressure Vessels";

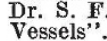

NORTH-EAST COAST INSTITUTION OF ENGINFRRS AND SHIPBUILDERS (in the Lecture Theatre of the Literary and Philosophical Society, Newcastle-upon-Tyne), at 6 p.m.- Prof. C. E. Inglis, F.R.S.: "The Vibrations by Means of Basic Functions" (Parsons Memorial Lecture).

\section{Saturday, December 16}

Pathological Societr of Great Britain and Ireland (joint meeting with the BIOCHEMICAI SOCIETY) (at the Royal Society of Medicine, 1 Wimpole Street, London, W.1), at 11 a.m.-Discussion on "Cancer".

QUEKETT Mronosoopical SoOrary (at the Royal Society, Burlington "House, Piccadilly, London, W.1), at 2.30 p.m.-Dr. W. S. Bristowe : "In Quest of Spiders".

\section{APPOINTMENTS VACANT}

APPLICATIONS are invited for the following appointments on or before the dates mentioned

GRADUATE LECTURER IN BIOLOGY, with qualifications in Anatomy and Physiology, in the Mining and Technical College, Crumlin-The Newport, Mon. (December 13).

A port, Mon. (December offcer, Leicestershire War Agricultural Executive Committee, 7 Friar Lane, Leicester (December 16).

Assistants (2), one in the MEChanical and one in the Electrioat. EARINEERING DEPARTMENT-The Principal and Secretary, Harris Institute, Preston (Deci mber 18)

ANALYST by an Engineering Establishment in Lancashire (works experience in the analysis of ferrous and non-ferrous metals and alloys essential)-The Ministry of Labour and National Service, Central (T. and S.) Register, Room 5/17, Sardinia Street, Kingsway, London, W.C.2 (quoting Reference No.F.1169.XA) (December 19).

LABORATORY ASSISTANT (Grade I) IN THF DEPARTMENT OF BOTANX -The Secretary, Bedford College for Women, Regent's Park, London,

Young ENGINEer on PHysicrst with good mathematical qualifications, for development work on Turbines-The Manager, Employment Thange, Warwick Road, Wallsend.

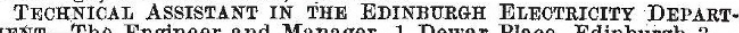
MaNT-The Engineer and Manager, 1 Dewar Place, Edinburgh 3 .

DIRECTOR of a comprehensive scheme for Recruitment, Training and education of personnel of all grades in all coalfields of the country - The Chairman, Mining Association of Great Britain, 53 Parliament Street, London, S.W.1.

LABORATORY ASSISTANT IN THE DEPARTMENT OF BOTANY-The Bursar and Acting Registrar, University College of North Wales, Bangor. 